\title{
Indian cashew food
}

\author{
Parashram Jakappa Patil* \\ The Institute for Natural Resources, University of Pune, Kolhapur, Maharashtra, India
}

\begin{abstract}
India has suitable geographical conditions for cashew cultivations hence it is one of the largest cashew producing country in the world. Cashew production mainly found in India in an around western ghatt. Cashews have a lower fat content than most other nuts, approximately $82 \%$ of their fat is unsaturated fatty acids, plus about $66 \%$ of this unsaturated fatty acid content are heart-healthy monounsaturated fats, similar to those found in olive oil. Since it is good for health cashews is a good idea, especially for persons with diabetes. Therefore, developed countries cashew is important food in their consumption bracket. Hence India's contribution in world's cashew food supply is very vital and trustworthy. The present research work will deal with to 1 . To study India's cashew processing and its mechanism, 2 . To understand importance of cashew as food. 3. To make glance on India's contribution on world cashew food supply. It is case study of India in context of supply cashew food to entire world.
\end{abstract}

\section{Introduction}

India has certain important horticulture crops which is contributes in Indian agriculture economy. Cashew is such versatile crop which is mainly belong to rural community. India has suitable geographical conditions for cashew cultivations hence it is one of the largest cashew producing country in the world. Cashew production mainly found in India in an around western ghatt. Numerous agriculture and natural resources having by Western Ghatt in that cashew is important agri resources. It is working like white gold for local people. It has made systematic effort for development of cashew in India. Separate infrastructure for cashew research and extension has been developed due to which cashew production grown in India tremendously. Indian Cashew is known world-wide for its excellent quality. India being a leader in cashew production is also world's largest producer, processor and exporter of cashew kernels [1-10].

\section{Statement of the problem}

India is major supplier of cashew food in the entire world. It is this country which providing cashew food to entire world form centuries. Hence it important to understand how India fulfill demand of cashew food of entire world. Assessment of India's cashew processing is vital in order to understand cashew as food, it is because it's going through various cashew processing stages. It effects on quality of food. Therefore, making glance on India's cashew processing and its dynamics would bring more focus on cashew as food.

\section{Objectives of the study}

1. To study India's cashew processing and its mechanism.

2. To understand importance of cashew as food.

3. To make glance on India's contribution on world cashew food supply.

\section{Hypothesis}

1. Cashew food is significantly impact on human health.

2. Indian is significantly contributing in world cashew food.

\section{India's export of cashew kernel}

Cashew-nut industry has the big export potential which has increasing the prospects of the industry. The following table clears the whole picture of the Indian cashew kernel export.

India is the second largest exporter of cashew kernels in the world. Table 1 shows the growth of cashew kernel export. The cumulative growth rate of cashew-nut production in respect of quantity of export and value of export is $(238.55 \%)$ and $(1128.48 \%)$ respectively. It indicates that India has been making progress in the cashew export sector over a period of time. India has a potential to become a world leader of cashew export. The export of cashew kernels gives valuable foreign exchange to the Government of India. The growth of cashew kernel exports seems satisfactory.

\section{India's export of cashew nut shell liquid}

The industry has many business dimensions. The export of cashew nut shell liquid is one of the important dimensions. The following given table focuses on the particular issue.

Cashew-Nut Shell Liquid Oil (CNSL) is an important by-product of cashew. It has huge export potential due to its distinct characteristics. Table 2 reveals the growth of CNSL export. The cumulative growth rate of cashew-nut production in respect of quantity of export and value of export is (193\%), (241\%) respectively. It shows export of CNSL has been making progress an over a period of time. Indian earns valuable foreign exchange by making export of CNSL. The growth of export seems good and is increasing continuously.

Correspondence to: Parashram Jakappa Pail, Social Scientist, Post Doc Fellow, Chairman, The Institute for Natural Resources, Kolhapur, Maharashtra, India, Tel: 919975360901; E-mail: patilparashram9@gmail.com

Key words: food, cashew, India, processing, world

Received: November 28, 2016; Accepted: December 26, 2016; Published: January 03, 2017 
Table 1. Export of Cashew Kernel from India.

\begin{tabular}{|c|c|c|c|c|}
\hline Year & Export Quantity (In M.T.) & Export Value (In Rupees in Lukas) & $\begin{array}{c}\text { Export quantity Cumulative } \\
\text { Growth (In \%) }\end{array}$ & $\begin{array}{c}\text { Export Value Cumulative Growth } \\
\text { (In \%) }\end{array}$ \\
\hline $1990-91$ & 49874 & 44224 & & \\
\hline 1991-92 & 47738 & 66909 & 95.71 & 151.29 \\
\hline $1992-93$ & 53436 & 74549 & 107.14 & 168.57 \\
\hline 1993-94 & 69884 & 104602 & 140.12 & 236.52 \\
\hline $1994-95$ & 77000 & 124602 & 154.38 & 281.75 \\
\hline $1995-96$ & 70334 & 124050 & 141.02 & 280.5 \\
\hline 1996-97 & 68663 & 128550 & 137.67 & 290.67 \\
\hline $1997-98$ & 76593 & 139610 & 153.57 & 315.68 \\
\hline 1998-99 & 75026 & 160990 & 150.43 & 364.03 \\
\hline 1999-00 & 92461 & 245145 & 185.38 & 554.32 \\
\hline 2000-01 & 89155 & 204975 & 178.76 & 463.49 \\
\hline 2001-02 & 97550 & 177680 & 195.59 & 401.77 \\
\hline $2002-03$ & 104137 & 193302 & 208.8 & 437.09 \\
\hline 2003-04 & 100828 & 180442 & 202.16 & 408.01 \\
\hline 2004-05 & 126667 & 270924 & 253.97 & 612.61 \\
\hline 2005-06 & 114143 & 251486 & 228.86 & 568.66 \\
\hline 2006-07 & 118540 & 245515 & 237.67 & 555.16 \\
\hline 2007-08 & 114340 & 228890 & 229.25 & 517.56 \\
\hline 2008-09 & 109555 & 299844 & 219.66 & 678.01 \\
\hline 2009-10 & 117991 & 280160 & 236.57 & 633.5 \\
\hline 2010-11 & 105775 & 281939 & 212.08 & 637.52 \\
\hline 2011-12 & 131760 & 439068 & 264.14 & 992.82 \\
\hline 2012-13 & 104015 & 406721 & 208.59 & 919.68 \\
\hline 2013-14 & 114791 & 505873 & 230.2 & 1143.88 \\
\hline 2014-15 & 118952 & 543285 & 238.55 & 1128.48 \\
\hline
\end{tabular}

Table 2. Export of Cashew-nut Shell Liquid from India.

\begin{tabular}{|c|c|c|c|c|}
\hline Year & $\begin{array}{l}\text { Export Quantity } \\
\text { (In M.T.) }\end{array}$ & $\begin{array}{c}\text { Export Value } \\
\text { (In Rupees in Lukas) }\end{array}$ & $\begin{array}{c}\text { Export quantity } \\
\text { Cumulative Growth (In \%) }\end{array}$ & $\begin{array}{c}\text { Export Value Cumulative Growth } \\
\text { (In \%) }\end{array}$ \\
\hline 1990-91 & 5658 & 556 & & \\
\hline 1991-92 & 4542 & 402 & 80 & 72 \\
\hline $1992-93$ & 4258 & 381 & 85 & 78 \\
\hline 1993-94 & 3625 & 290 & 74 & 23 \\
\hline 1994-95 & 3807 & 244 & 77 & 31 \\
\hline $1995-96$ & 760 & 145 & 24 & 14 \\
\hline 1996-97 & 1735 & 277 & 41 & 37 \\
\hline $1997-98$ & 4446 & 717 & 88 & 116 \\
\hline 1998-99 & 1572 & 326 & 38 & 186 \\
\hline 1999-00 & 764 & 184 & 24 & 161 \\
\hline 2000-01 & 2246 & 3894 & 40 & 828 \\
\hline 2001-02 & 1814 & 419 & 33 & 203 \\
\hline 2002-03 & 7215 & 925 & 128 & 294 \\
\hline 2003-04 & 6926 & 703 & 123 & 255 \\
\hline 2004-05 & 7474 & 791 & 132 & 270 \\
\hline $2005-06$ & 6405 & 709 & 114 & 257 \\
\hline 2006-07 & 5589 & 920 & 100 & 294 \\
\hline $2007-08$ & 7813 & 1197 & 139 & 343 \\
\hline 2008-09 & 9099 & 26.06 & 160 & 200 \\
\hline 2009-10 & 11227 & 27.62 & 198 & 247 \\
\hline 2010-11 & 12051 & 33.77 & 212 & 265 \\
\hline 2011-12 & 13575 & 59.46 & 239 & 298 \\
\hline 2012-13 & 9192 & 29.84 & 162 & 202 \\
\hline 2013-14 & 9489 & 38.61 & 167 & 208 \\
\hline 2014-15 & 10938 & 55.81 & 193 & 241 \\
\hline
\end{tabular}




\section{India's cashew export market}

India's cashew export is very large. It spread almost throughout the world. This spread indicates depth of India's cashew export market that makes the Indian cashew-nut industry a leader of world cashew economy.

Table 3 explain the depth of India's cashew export market \& how its spread across the world. It also reveals the export potential and availability of export market for India cashew-nut industry which needs to explore. It also shows that American and European countries are largely importing cashew kernel from India. It means India has strong presence in their cashew market.

\section{India's cashew-nut shell liquid oil export market}

Along with quality cashew kernel Indian cashew-nut industry is producing quality cashew-nut shell liquid oil which also exportable. Indian cashew-nut industry has big market for CNSL.

Table 4 explains the India's market for CNSL, India is also having very good market for CNSL which enhance the prospects of Indian cashew-nut industry as well as India's cashew export sector. CNSL oil is use in industries hence there is good demand from industrially developed countries. USA \& China are the top most import of Indian cashew-nut shill liquid oil [11].

Table 3. Export of Cashew Kernels from India.

\begin{tabular}{|c|c|c|}
\hline Countries & $\begin{array}{c}\text { Quantity } \\
\text { (M.T.) }\end{array}$ & $\begin{array}{c}\text { Value } \\
\text { (Rs. Cores) }\end{array}$ \\
\hline U.S.A & 35236 & 911.31 \\
\hline U.A.E & 12295 & 393.31 \\
\hline Netherlands & 11178 & 289.02 \\
\hline Japan & 5944 & 159.16 \\
\hline Saudi Arabia & 3386 & 107.53 \\
\hline U.K. & 2798 & 71.76 \\
\hline France & 3623 & 90.12 \\
\hline Spain & 2634 & 69.14 \\
\hline Germany & 1739 & 41.51 \\
\hline Belgium & 2986 & 72.47 \\
\hline Singapore & 1692 & 41.31 \\
\hline Italy & 1194 & 29.11 \\
\hline Greece & 1311 & 35.36 \\
\hline Thailand & 733 & 21.57 \\
\hline Australia & 1359 & 32.70 \\
\hline Russia & 484 & 13.53 \\
\hline Canada & 678 & 16.53 \\
\hline Kuwait & 1001 & 31.19 \\
\hline Egypt & 1184 & 37.72 \\
\hline Algeria & 221 & 6.33 \\
\hline Turkey & 1346 & 36.56 \\
\hline Korea Rep. & 717 & 20.25 \\
\hline Jordan & 1093 & 31.07 \\
\hline Norway & 727 & 19.09 \\
\hline Syria Arab Rep & 850 & 25.87 \\
\hline Honk Kong & 530 & 15.14 \\
\hline Others & 8819 & 17.23 \\
\hline Total & 105755 & 220.71 \\
\hline
\end{tabular}

Table 4. Export of Cashew-Nut Shell Liquid Oil from India during.

\begin{tabular}{|l|c|c|}
\hline Countries & Quantity (M.T.) & Value (Rs. Cores) \\
\hline U.S.A & 5374 & 12.05 \\
\hline China & 3142 & 8.39 \\
\hline Korea Rep. & 1697 & 5.83 \\
\hline Japan & 712 & 2.16 \\
\hline Taiwan & 122 & 0.80 \\
\hline Slovenia & 267 & 1.13 \\
\hline Indonesia & 160 & 0.46 \\
\hline U.K. & 0 & 0.00 \\
\hline Singapore & 153 & 0.99 \\
\hline Iran & 0 & 0.00 \\
\hline Others & 424 & 1.90 \\
\hline Total & 12051 & 33.77 \\
\hline Source: CPCI & & \\
\hline
\end{tabular}

\section{Importance of cashew food}

Cashew is very significant having tremendous health benefits hence it is being loved across the world. Following are the some of the benefits of cashew food.

- $\quad$ Prevents Cancer: It is most important of cashew food that it prevents cancer. Proanthocyanidins are a class of flavonols which fight against tumor cells by stopping them to divide further. These proanthocyanidins and high copper content in cashew nuts help fight against cancerous cells and keeps you away from colon cancer.

- Healthy Heart: Cashew is helpful for making healthy heart. Cashews contain low fat content when compared to other nuts and that too in the oleic acid form which is very healthy for heart. They are cholesterol free and the antioxidants present keeps you away from heart diseases.

- Blood Pressure: Cashew nuts lower blood pressure with the help of magnesium present in them.

- Helps Hair: Copper is the mineral which helps hair get that color.

- Healthy Bones: Like calcium, magnesium is also important for bone health which is the main content in cashew nuts.

- Healthy Nerves: Magnesium is stored on the bones surface which prevents calcium from entering the nerve cells and thus keeps the blood vessels and muscles relaxed. Insufficient amount of magnesium can lead calcium to enter the blood vessels leading them to contract. It also leads to high blood pressure, migraine headache etc.

- $\quad$ Prevents Gallstones: Daily intake of cashewnut can reduce the risk of developing gallstones up to $25 \%$.

- Helps in Weight Loss: Even though cashew nuts are considered as fats, it contains good cholesterol. So, contrary to popular belief, those who eat cashews at least twice a week gain less weight when compared to those who eat less.

- Anti-oxidants: Selenium, copper, magnesium etc. act as cofactors for many enzymes.

- Helps Digestion: Cashew nuts help in growth and development, nucleic acid synthesis and digestion

- High on Vitamins: Cashew nuts are rich in vitamins like riboflavin, pantothenic acid, thiamin, niacin etc. These vitamins keep you safe from sideroblastic anemia, pellagra, etc. 
- Healthy Gums and Teeth: As mentioned before, the magnesium content present in cashew nuts is very good for bones. So, it gives healthy teeth as well as strong gums to hold them [12-14].

- $\quad$ Pleasant sleep: After menopause, these cashew nuts can give you relaxed and pleasant sleep during nights.

- $\quad$ Free Radicals: Cashew nuts help our body to utilize iron properly and eliminate free radicals which cause health problems.

- Macular Degeneration: Cashew nuts can filter Sun's UV rays and protect us from macular degeneration.

Thus, cashew consumption is very vital for human heath, it is providing numerous health benefits. It is one of the rear food which content so much of positive input for health. Hence India is providing important role in world health protection by providing cashew food to entire world.

\section{Cashew processing methodology}

Cashew processing is the systematic activity involving many processes. Over a period, there has been improved in cashew processing machinery and technology. Initially cashew processing was manual because of which there was big loss of cashew kernel. But with commercialization of cashew-nut industry there are many innovations in cashew processing machinery which produce quality cashew kernel. This article focused on cashew processing and packaging machinery. The following are the steps of cashew processing machinery and its technology are given in detailed.

Cleaning, sizing and conditioning: The first cashew processing operation is the removal of foreign matter and dirt from the nuts. The nuts are collected from the ground after falling from the trees. Apples are removed along with other foreign matter. At the simplest level, the nuts are sieved by hand using a three-quarter inch $(20 \mathrm{~mm})$ mesh sieve to remove dust and dirt (ITDG, 2000). The cleaned nuts are then conditioned in preparations for removal of shell. Conditioning increases the brittleness of the shell and thereby facilities its removal.

Soaking: The next step is to soak the nuts in water to avoid scorching them during the roasting operations. This can be done by placing the nuts in a (40-45) gallon drum or vat and filling it with water until all the nuts are cover. After being left to stand for about ten minutes, the water should then be drained off via a plug near the base of the drum. The should then be left for periods of not less than four hours to allow the water left on the surface on the nuts to be absorbed. The process of covering the nuts with water, darning and standing should be repeated with the same nuts about three times until a moisture content of $9 \%$ is reached. Whether the production output runs from (2-10) tons per day, a simple cleanings and conditioning arrangement can be used. Two people open the sacks of harvested nuts on a stand and clean the raw storage until the soaking process begins. Two vats are useful because one can be emptied while the other is being filled (ITDG, 2010).

Roasting of cashew: There are different methods which are using for cashew roasting in India such as Sun Roasting, Open Pan Roasting, Drum Roasting and Oil Bath Roasting and stem roasting. At present in India stem roasting is apply hence we would focus on that only in detailed. The steam process was an innovation of 1980s. This process involves roasting by direct application of stem to dry nuts. Raw nuts are stem cooked at about $120-140 \mathrm{ibs} / \mathrm{sq}$ inch pressure, then nuts are allowed to cool for 24 hours and taken for shelling. Shell oil can be extracted in later stages by crushing. Nuts are shelled by hand and leg operated shelling machines (DCCD, 2010) [15-19].
Cashew shelling: Cashew- nuts after roasting and cooling are to be shelled to remove kernels. It is careful process it has to be take sufficient care while making cashew shelling. The hands have to be protected from cashew-nut shell liquid oil which is highly corrosive, hand gloze should be used for cutting work. The commercial cashew processing units use foot operated shell cutters (Mechanical Devise) for shelling. This devise is consists of a pair of blade (knives) shaped in counter of half a unit, which could be operated by foot. The blades cut through the shell all around the nut, leaving the kernel untouched. After shelling the kernels and shell pieces are separated manually. The nuts have to be grouped into various sizes matching of pair of blades of appropriate size (DCCD, 2010). Now day's automatic cashew cutting machine used by processors which replace manual cashew cutting work. It also reduce workforce [20].

Draying: After the shelling is over next step is to draying cashew kernel. The kernels after shelling will have moisture content of more than $6 \%$. Drying of kernels is necessary to prevent fungus attack during subsequent storage and to facilitate peeling of testa. The kernels are to be dried to moisture content of about $4-5 \%$. This is done by drying the chambers in hot chambers at 70-80 $\mathrm{c}$ in perforated trays for about 6-8 hours. Uniform drying could be achieved with a cross flow drier using forced hot air circulations through the kernel layers. In order to uniform drying, the position of trays has to be changed frequently, as scorching may occurs at hotter places. Excess drying of kernels becoming very brittle resulting in higher breakages. After drying the kernels are kept in the moist chamber for 24 hours which facilities easy removal of testa (peeling) and reduced broken kernels (DCCD, 2010).

Peeling: After drying next step is of cashew peeling. In this stage testa is loosely attached to cashew kernel, although few kernels may have already lost tests during prior operations. Manual peeling is generally performed by gently rubbing with fingers. Still those parts attached to kernels are removed with use of Bamboo knife. Approximately 10-12 $\mathrm{kg}$ kernels could be peeled by one person in a day [21].

Grading: Here cashew kernels are graded as per its color, taste, weight, and size, its increase commercial value of cashew kernels. Commercial value of cashew kernel is depending on individual grade.

Packing: The normal packing for export is in air-tight tins of 25lbs in weight. The packing needs to be impermeable as cashew kernels are subject to rancidity and go stale very quickly. The tin will be familiar to most tropical countries as it is a replica of the four-gallon kerosene or paraffin oil tin. If possible the tins are made locally as movement of empty tins overseas is expensive. Alternatively, it might be arranged to purchase components are finish the manufacturing locally. This may be done by arrangement with tin manufactures. The output of a tin manufacturing line is usually too large for one consumer but some cashew-nut processors have in fact installed their own tin making plant and supply other processors [21].

After filling and weighing, the cap should be soldered on in preparation for the 'vita pack' process. This consists of removing all air from the tin and substituting this with carbon dioxide $\left(\mathrm{CO}_{2}\right)$. The advantages of packing cashew kernels in carbon dioxide are twofold. Firstly, carbon dioxide is an inert gas and will not support life. Any infestation that may have been present is therefore arrested. Secondly, carbon dioxide is soluble in cashew oil and goes into solution as soon as the seals are made. In a short space to time, it can be seen that a decrease in pressure takes place as the carbon dioxide goes in to solution and the sides, top and bottom are drawn inwards. Thus, the kernels are held tight in the tin, preventing movement and breakages 
during transport. Carbon dioxide, being a heavy gas causes the upward displacement of air and will remain in the tins after the filling process. Some large- scale machines will operate on six tins at a time, creating a vacuum in each and then filling with carbon dioxide. Some processors do not have vacuum pumps and displace the air in the tin be feeding in carbon dioxide through small hole in the bottom of a side of the tin. The carbon dioxide value is turned off when all the air has been replaced. The holes in the tin are then sealed, with the hole at the bottom of the side of the tin being done first, and the one on the top last [21]. Thus, cashew-nut go in different process and after that it's become eatable product. Over period of time due to advancement in processing technology, process has become simplified and producing more. Most of the processing innovations had been took place in Indian cashew factory. At present all cashew processing machinery has been developed India only. Innovation in cashew processing machinery over a period of time is one of the reason that Indian is global leader in world cashew economy [22,23].

\section{Conclusion}

Indian is pioneer in cashew business which is very providing cashew to entire world. Cashew as food is very important especially in American and European countries. It has rich proteins and vitamins hence it more popular. Since cashew processing is going various stages one has to careful about it otherwise its effects on its quality. Being largest cashew producing, processing and exporting country in the world is directly contributing in food security of the world. Cashews have a lower fat content than most other nuts, approximately $82 \%$ of their fat is unsaturated fatty acids, plus about $66 \%$ of this unsaturated fatty acid content are heart-healthy monounsaturated fats, similar to those found in olive oil. Since it is good for health cashews is a good idea, especially for persons with diabetes. Therefore, developed countries cashew is important food in their consumption bracket. Hence India's contribution in world's cashew food supply is very vital and trustworthy. Cashew food is providing numerous benefits to human health such as prevention of cancer, healthy heart, healthy bones, blood pressure, Prevents Gallstones, helps hairs, free Radicals, sound sleep, Healthy Gums and Teeth, vitamins, proteins, weight loose, Anti-oxidants, digestion, healthy nerve, sleep etc. Hence India's contribution in human health by providing cashew to entire world is significant.

\section{References}

1. Patil Parashram J (2012) Problems and Prospects of Cashew-nut Industry of Kolhapur District, Shivaji University, Kolhapur.

2. Steven J (1994) Private Trader Response to Market Liberalizations in Tanzania's Cashew Nut Industry, the World Bank Agricultural and Natural Resources Department Agricultural Policies Division.
3. Praveen KV (2004) Consumer Perspective on Cashew Procurement, Indian Cashew Convention 2004, Raddission White Sands Ressorts Goa.

4. Brijesh K (2004) Supply and Demand Dynamics 2004 Beyond Raw Cashew nuts and Kernels', Indian Cashew Convention 2004, Radisson White Sands Ressort Goa.

5. Papademtriou MK, Herath EM (1998) Integrated Production Practices of Cashew in Asia, Food and Agriculture's Organization of the United Nations.

6. Mcmillan M, Roderick D, Welch KH (2002) When Economic Reform Goes Wrong: Cashew in Mozambique, National Bureau of Economic Research 1050 Massachusetts Avenue Cambridge, MA02138.

7. Nicua MP (2000) Economic Analysis of Smallholder Cashew Development Mozambique's Northern Provinces of Nampula, Michigan State University.

8. Meera M (2004) Managing the Price for Cashew, Indian Cashew Convention 2004, Radission White Sands Ressort Goa.

9. Mahajan SS, Patil PJ (2009) Role of Cashew Nut Industry in Development of Hilly Region In Kolhapur District, National Conference on Development of Hilly Region: The Problems and Potentials,

10. Nair H (2004) Marketing Nutrition-for Cashew, Indian Cashew Cashew Convention 2004, Raddission White Sands Ressorts Goa.

11. Naik AN, Kovlag AK, Wader LK (2006) Marketing of Cashew Kernels in North District of Goa, Indian Journal Agriculture Marketing' publication of Indian Society of Agriculture Marketing 112-A RachnaVishwa K T Nagar Kutol Road Nagpur.

12. Pillai A (2004) Increasing Domestic Kernels Consmpations, Indian Cashew Convention 2004, Raddission White Sands Ressorts Goa.

13. Rao BV, Swamy KRM, Bhat MG (2006) Cashew, (Ed.), Plantation Crops, Paratha Sankar Basu, Kolkata.

14. Ramaswamy P (1967) Mechanization in Cashew Processing and Its Implications for Indian Cashew Industry, Indian Journal Agriculture Marketing, Published by the Directorate of Marketing and Inspection ,Ministry of Food, Agriculture Community Development \& Cooperation (Department of Agriculture), Government of India , Nagpur.

15. Giridhar PG (2004) Cashew International Market Dynamics 2004, Indian Cashew Convention 2004, Radisson White Sands Ressort Goa.

16. Sandhu HK (1982) An Econometric Analysis of Indian Export -Share of Cashew Kernels in the World Trade, Indian Journal of Agricultural Economics.

17. Pankaj S (2004) World Cashew Trade Scenario \& Issues, Indian Cashew Convention 2004, Radisson White Sands Ressort Goa.

18. Walter DS (2004) Increasing World Cashew Kernels Consumption, Indian Cashew Convention 2004, Raddission White Sands Ressorts Goa.

19. Vellingiri D, Thiyagarjan D (2007) The Cashew Nut Industry in India Growth and Prospectus, The ICFAI Journal of Agricultural Economics Hyderabad.

20. Wadkar SS, Talathi JM, Torane SR (2005) Performance of Cashew Export from India, Agricultural Marketing.

21. Zam-Ali SH, Judge EC (2004) Small Scale Cashew Nut Processing, Publishing Management Service Information Division, FAO, Caracalla, Rome, Italy.

22. http://worldcashew.com/two-specific-schemes-to-save-on-customs-duty-1/

23. http://www.stylecraze.com/articles/benefits-of-cashew-nuts/

Copyright: (C2017 Patil PJ. This is an open-access article distributed under the terms of the Creative Commons Attribution License, which permits unrestricted use, distribution, and reproduction in any medium, provided the original author and source are credited. 